\title{
THE EFFECT OF THE COVID-19 PANDEMIC ON THE CROATIAN TOURIST SECTOR
}

\author{
Siniša Bogdan \\ Luka Šikić \\ Suzana Bareša
}

https://doi.org//10.20867/tosee.06.8

\begin{abstract}
Purpose - The COVID-19 pandemic, unprecedented in terms of the speed at which it spread globally, affected the whole world swiftly after the initial outbreak and has produced heterogeneous effects on various industrial sectors and particularly pronounced effects on the tourism industry. This paper analyses the effect of the spread of the COVID-19 pandemic through Europe on the tourist stocks in Croatia by means of application of the event study methodology. Methodology - The analysis starts with a descriptive overview of the market-wide performance of different sectors in the period before, during and after the initial pandemic outbreak and subsequently explicitly tests for the COVID-19 outbreak effects on the tourist sector. First, a 35day event window is specified so that important events related to the pandemic can be identified. Second, the first officially reported COVID-19 incidence in Italy and the World Health Organization's declaration of a global pandemic are used as identified events in a shorter 10day window event study estimation.

Findings - The results robustly point to the significant negative effect of the COVID-19 pandemic on the returns of tourist stocks on the Zagreb Stock Exchange. However, the overall results do not provide evidence of the relatively stronger COVID-19 effects on the tourist sector, but rather equal effects across different sectors.

Contribution - This research offers a novel comprehensive review of the literature regarding the research topic and provides insights into the sectoral effects of the global financial shock caused by the COVID-19 pandemic on the local market. As this pandemic is increasing the market volatility, this research will be of importance to fund managers and carries implications for economic policy in terms of sectoral stimulus distribution and debt refinancing.
\end{abstract}

Keywords: stock market, stocks, volatility, abnormal.

\section{INTRODUCTION}

The coronavirus pandemic spread around the globe in just a few months after the first case was registered, triggering substantial consequences in the form of threats to human health and life, great economic losses and psychological fear. The presence of the virus has prevented potential tourists from feeling safe in the tourist destinations and caused a comprehensive interruption in the functioning of tourism business. According to the UNWTO (2021), international tourist arrivals (overnight visitors) dropped by $74 \%$ in 2020 compared to 2019 , due to the massive drop in tourist demand and newly issued travel restrictions. The pandemic has produced a loss of USD 1.3 trillion in export revenues, which is an eleven-times greater loss compared to the global financial crisis of 2008. The UNWTO forecasted that it could take between 2.5 and up to 4 years for international tourism to return to the level experienced in 2019. The effectiveness of vaccines and the percentage of those vaccinated in the population will certainly play an 
ToSEE - Tourism in Southern and Eastern Europe, Vol. 6, pp. 109-123, 2021.

S. Bogdan, L. Šikić, S. Bareša: THE EFFECT OF THE COVID-19 PANDEMIC ON THE CROATIAN ...

important role and are expected to reduce the number of new cases, as do the mitigation of travel restriction measures and the restoration of consumer confidence. The consequences of the pandemic are especially pronounced in tourism-dependent countries like Croatia.

According to the UNWTO (2021), Croatia is among the ten most vulnerable countries according to the criteria of the direct impact of tourism on the share of GDP. More precisely, in the first place is Macao (China) with $48 \%$, followed by Fiji with $13 \%$, Jordan $12 \%$, Spain $12 \%$ and Croatia with $11 \%$. Many countries have introduced travel restrictions and, in light of the fact that the share of foreign tourists in Croatia is $89 \%$ (UNWTO 2021), negative financial results are expected from companies that are directly or indirectly involved in tourism. Besides the aforementioned facts, tourism is a significant contributor to national exports (35\%) (UNWTO 2021) and this contraction will have negative macroeconomic consequences. Although Croatia achieved a record high in 2019 in terms of the total number of arrivals and overnight stays of domestic and foreign tourists in 2020, there was a steep decline due to the global pandemic in 2020, compared to 2019. The pronounced drop in the tourism figures has spilled over on to the capital market and caused turmoil, so the purpose of this research is to investigate how tourism stock prices have responded to the outbreak of the COVID-19 pandemic by using event study methodology. This methodology has proven to be especially useful in identifying the effect of a particular event on stock market returns.

This study contributes to the literature by analysing the impact of the global COVID-19 pandemic on the tourism sector in Croatia. As a practical implication, this study will be particularly useful to current and potential investors as well as to policymakers during this and other future unexpected crises. The remainder of this study is structured as follows: Section 2 performs an overview of Croatian tourism before and during the COVID-19 pandemic, Section 3 outlines a detailed literature review, Section 4 presents the data and methodology and Section 5 reports the results and discussion of the empirical research, while the last section summarises the conclusion, limitations and future research recommendations.

\section{TOURISM IN CROATIA BEFORE AND DURING THE COVID-19 PANDEMIC}

The Republic of Croatia systematically follows global tourist trends and is well positioned on the European tourist market. It is recognised as a stable, safe tourist destination with beautiful and rich natural and cultural-historical heritages. The Croatian tourism sector has been successful since Croatia's independence and accession to the European Union, and consistently recorded enviable results prior to the outbreak of the coronavirus pandemic in 2020. According to the data published on the official website of the World Health Organization-WHO, by 20 April 2021, a total of 141,754,944 confirmed cases of COVID-19 had been recorded, as well as 3,025,835 deaths worldwide. According to the same source, from 3 January 2020 to 20 April 2021, 310,306 confirmed COVID-19 cases and 6,643 deaths were recorded in Croatia in the total population of $4,058,165$, and it can therefore be concluded that Croatia was severely affected by the pandemic. 
ToSEE - Tourism in Southern and Eastern Europe, Vol. 6, pp. 109-123, 2021.

S. Bogdan, L. Šikić, S. Bareša: THE EFFECT OF THE COVID-19 PANDEMIC ON THE CROATIAN ...

The SARS-CoV-2 virus has affected the whole world and caused historically unprecedented problems in all aspects of social and economic life. It has greatly affected global economic activities. Measures taken to prevent the virus spreading (social distancing, traffic restrictions, restrictions on commercial activity, borders closures etc.) strongly have affected the service sector - tourism and hospitality. The analysis of the selected indicators of tourism development in Croatia before and at the time of the COVID-19 pandemic in Croatia demonstrates how much the pandemic has affected the results in tourism.

Table 1: Tourist arrivals and overnight stays in Croatia in the period 1980-2020

\begin{tabular}{|c|c|c|c|c|c|c|c|c|c|c|c|}
\hline & 2010 & 2011 & 2012 & 2013 & 2014 & 2015 & 2016 & 2017 & 2018 & 2019 & 2020 \\
\hline $\begin{array}{l}\text { Tourist arrivals } \\
\text { (in 000) }\end{array}$ & 56,217 & 60,110 & 62,507 & 64,617 & 66,270 & 71,437 & 77,919 & 86,200 & 89,652 & 91,243 & 40,794 \\
\hline $\begin{array}{l}\text { Tourist nights } \\
\text { (in 000) }\end{array}$ & 10,405 & 11,211 & 11,599 & 12,233 & 12,914 & 14,175 & 15,463 & 17,431 & 18,667 & 19,566 & 7,001 \\
\hline
\end{tabular}

Source: Ministry of Tourism 2020 (Tourism in numbers 2019, 11); Croatian Bureau of Statistics (Tourist arrivals and nights, 2020).

According to a historical review of data on tourist arrivals and overnight stays in Croatia (Table 1), constant growth in tourist arrivals and tourist overnight stays can be observed until 2020. If we compare the nights and arrivals in 2019 with those from 2010, it could be stated that the results almost doubled. Despite the favourable results, a sharp decline followed in 2020 , with a decrease by $64.2 \%$ in tourist arrivals and a decrease by $55.3 \%$ in overnight stays in commercial accommodations in 2020, compared to 2019. This decline in arrivals and overnight stays affected both domestic and foreign tourists, and was more pronounced among foreign tourists, which can be seen in Charts 1 and 2 .

Figure 1: Arrivals and overnight stays of foreign and domestic tourists in Croatia in the last five years (before and during the pandemic)
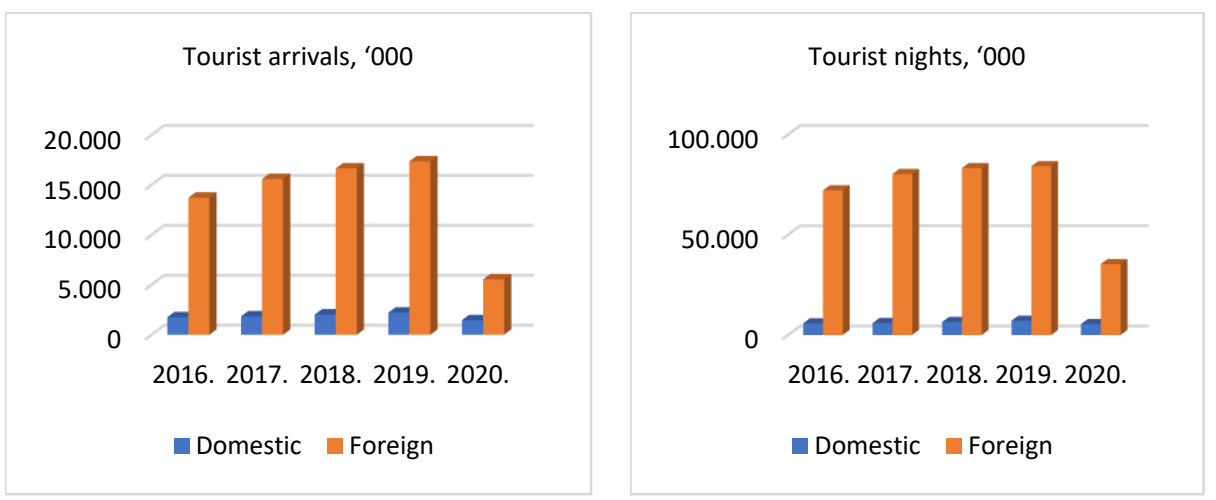

Source: Croatian Bureau of Statistics (Statistics in line)

According to the data from Figure 1, it can be concluded that the decline in domestic tourist arrivals in $2020(-34.24 \%)$ is much smaller compared to the decline of foreign tourist arrivals (-68.05\%). The same effect is present in overnight stays. Domestic 
ToSEE - Tourism in Southern and Eastern Europe, Vol. 6, pp. 109-123, 2021.

S. Bogdan, L. Šikić, S. Bareša: THE EFFECT OF THE COVID-19 PANDEMIC ON THE CROATIAN ...

overnight stays in 2020 decreased by $23.68 \%$, while overnight stays involving foreign tourists experienced a decrease of $57.95 \%$. These results are a consequence of the fear of the COVID-19 pandemic and lockdown measures.

\section{LITERATURE REVIEW}

The literature review is divided into three parts. The first part emphasises the importance of the event study methodology in finance, since it is dominantly applied in that field. The second part highlights the topic based on the extensive number of papers over the past year that have researched the impact of the pandemic on the stock market using various methodologies. The third part of the literature review presents the results of research papers that used the event study methodology to analyse the effects of the COVID-19 pandemic on stock markets.

The Event study methodology is used in a variety of application settings with the aim of measuring the impact of unforeseen or unanticipated events on prices or business performance. This methodology has therefore found wide usage in the field of finance for measuring corporate announcements on financial performance, investor behaviour or similar. The implicit assumption for the application of event study methodology is that markets are efficient, i.e. publicly available information is reflected in the prices of securities, so it has been used in economics for testing market efficiency on the capital market (Kothari and Warner 2007). However, Novak (2019) rejected the weak-form efficiency hypothesis on the Croatian capital market. Two of the first authors who demonstrated the usefulness of the event study methodology were Ball and Brown (1968), who researched the impact of earnings surprises on stock prices. Brown and Warner (1980) compared different event study methodologies and concluded that complicated methodologies will not benefit from better results in comparison with a simple one-factor market model. Asquith and Mullins (1983) concluded that initiating a dividend policy as a means of providing information has a strong and positive impact on the market reaction. Miletić (2011) analysed the impact of dividend announcements on the Croatian capital market by using the event study methodology. Results confirmed that an increase or decrease in a dividend significantly affected the stock price in the same direction, while a dividend retention had no effect on the stock price. Škrinjaric and Orlović (2019) applied the event study methodology in order to test whether political events regarding the Agrokor group of companies affected stock prices. Their results indicate that stocks which belonged to Agrokor suffered from lowering returns, while other liquid stocks on the Zagreb Stock Exchange were not affected.

No pandemic in human history can compare to the coronavirus pandemic in terms of the strength of its impact on the world's stock markets (Baker et al. 2020). Albulescu (2020) researched official announcements regarding new COVID-19 cases and the death ratio on the financial markets volatility index (VIX). The author concluded that new cases reported outside China have a positive impact on the VIX, death ratio has a significant positive impact on the VIX and the spread of the COVID-19 virus increases financial volatility. Chia et al. (2020) researched the relation between the Malaysian stock market and variables related to COVID-19, and their results suggest that daily new cases had a negative, but insignificant impact on the stock indices returns. On the other hand, authors 
ToSEE - Tourism in Southern and Eastern Europe, Vol. 6, pp. 109-123, 2021.

S. Bogdan, L. Šikić, S. Bareša: THE EFFECT OF THE COVID-19 PANDEMIC ON THE CROATIAN ...

have also found that movement control orders had a significant and positive impact on all stock indices' returns, which is quite surprising. There is a significant body of recent research that explores the impact of COVID-19 on the capital markets (Mazur et al. 2021; Ramelli and Wagner 2020; Phan and Narayan 2020; Narayan et al. 2020; Contessi and De Peace 2021; Erdem 2020; Onali 2020; Rahman et al. 2021; Harjoto et al. 2020; Okorie and Lin 2021; Alam et al. 2021).

Some papers have investigated the effect of the coronavirus pandemic by using the event study methodology. Panyagometh (2020) used a sample of 46 stocks listed on the Stock Exchange of Thailand in order to analyse stock price reactions during the pandemic. After applying the event study methodology in order to measure abnormal returns and volatility empirically, the research results suggest that the majority of stocks on the Stock Exchange of Thailand has been negatively affected by the COVID-19 pandemic. On the other hand, the author found that some stocks had experienced positive returns, in particular the stocks from the commerce sector which are involved in the distribution of pharmaceutical products and services. Irfan et al. (2021) analysed the impact of COVID19 on the performance of the Indian Stock Exchange and Indonesian Stock Exchange. The author included three different event windows to check results in different time periods. The analysis of both countries showed opposite results, since the Indian stock market demonstrated a downward-sloping trend after the WHO declaration, while its Indonesian counterpart experienced an upward-sloping trend. He et al. (2020) investigated the impact of COVID-19 on the stock prices of different Chinese industries. The authors concluded that pandemic has greatly affected transportation, mining, electric and heating, and environmental industries, while manufacturing, information technology, education and health-care industries have resisted the impact of the COVID19 pandemic. Liu et al. (2020) evaluated the short-term impact of COVID-19 on the stock indices of various countries (Japan, Korea, Singapore, USA, UK etc.) Their results suggested that COVID 19 had a significant negative effect on all the countries affected. The authors found that the Asian stock markets had more negative abnormal returns compared to other countries. Their regression results also support the evidence of an adverse effect of the confirmed cases on the stock indices' abnormal returns. Kandil Göker et al. (2020) researched the impact of COVID-19 on the Istanbul sector indices' returns by applying the event study methodology. The authors confirmed that most of the sectors have negative abnormal returns. Sectors which were hit most are sports, tourism and transportation.

\section{METHODOLOGY}

\subsection{Data}

This analysis uses a data sample of 23 traded tourist firms retrieved from the Zagreb Stock Exchange (ZSE) in the period between the first trading day in 2019 and 13 April 2021. Due to the low liquidity, i.e. infrequent trading and low turnover, the initial sample is reduced to the final empirical sample of 12 firms according to the criteria of a minimum of 100 trading days over the sampled period. For these 12 firms, the daily closing stock prices are used in order to calculate the daily percentage returns. As COVID-19 pandemic was gaining worldwide momentum prior to spreading to the 
ToSEE - Tourism in Southern and Eastern Europe, Vol. 6, pp. 109-123, 2021.

S. Bogdan, L. Šikić, S. Bareša: THE EFFECT OF THE COVID-19 PANDEMIC ON THE CROATIAN ...

Europe, we divide the time period into three parts: a pre-epidemic part ranging from the first trading day in 2019 until one week before the first reported case in Italy (21 February 2020), the ongoing pandemic from the first officially reported COVID-19 incidence in Italy until one week after the lockdown was introduced in Croatia (19 March 2020.) and a post-event period from 26 March 2020 until the end of the sample period (13 April 2021). The reason for specifying the event period loosely, i.e. one week before the first COVID-19 incidence in Italy and one week after the lockdown in Croatia, is to allow for the uncertainty and new information set to become incorporated into the market valuations due to the novelty of the pandemic event and media reporting despite a policy reaction lag related to the pandemic outbreak.

An overview of the Croatian capital market's reaction to the spread of the COVID-19 pandemic in Europe is summarised in Table 2. The COVID-19 pandemic caused a significant drop in the overall market valuation (CrobexTr) by $25.9 \%$ and all sectoral indices. The Crobex Nutrition Index (CrobexNutr) had the biggest relative drop (26.1\%), followed by the Crobex Tourist Index (CrobexTur), which lost $25.2 \%$ of its value. The negative pandemic effect seems even more pronounced, since the overall stock market trend was positive and gained 19\% from the beginning of the analysed period. The worst performing sector in that period was construction (CrobexKonstr), which lost $31 \%$ of its value. During the post-event period, a significant overall market rebound can be observed as the CrobexTr index rose by $17.7 \%$, followed by the positive performance of all sectors. The tourist sector had the worst performance relative to other sectors in the pre-event period $(-0.4 \%)$, but reacted very similarly to the overall market during the event period. The rebound of the tourist sector was only slightly better than the market average, but significantly smaller than other sectors, like the construction and food sectors. It is interesting to note that the standard deviation of the tourist sector return remained lower than the average market during the event and in the post-event period, implying a lower investment risk. Furthermore, the standard deviation of the tourist sector return is lower relative to the other sectors in all periods, indicating that the effect of the COVID-19 pandemic was not strongest in the tourist sector, but rather very similar to the market average. It is also important to note that the market rebound after the event was stronger in industry and construction than in the tourist sector.

Table 2: Overview of the market returns over the analysed period

\begin{tabular}{llccccc}
\hline Pandemic & Index & Total Change $(\%)$ & Mean & Stdev & Min & Max \\
\hline Ongoing & CrobexInd & -24.36 & -0.609 & 4.116 & -14.69 & 7.48 \\
Ongoing & CrobexKonstr & -16.62 & -0.416 & 4.652 & -15.3 & 10.9 \\
Ongoing & CrobexNutr & -26.15 & -0.654 & 3.719 & -12.46 & 6.43 \\
Ongoing & CrobexTr & -25.88 & -0.647 & 3.363 & -11.31 & 5.46 \\
Ongoing & CrobexTur & -25.2 & -0.63 & 3.361 & -10.98 & 6.57 \\
Post & CrobexInd & 40.059 & 0.159 & 1.282 & -3.772 & 8.3 \\
Post & CrobexKonstr & 77.072 & 0.306 & 2.34 & -6.538 & 8.2 \\
Post & CrobexNutr & 9.04 & 0.036 & 1.423 & -11.1 & 6.01 \\
Post & CrobexTr & 17.694 & 0.07 & 0.631 & -1.821 & 3 \\
\hline
\end{tabular}


ToSEE - Tourism in Southern and Eastern Europe, Vol. 6, pp. 109-123, 2021. S. Bogdan, L. Šikić, S. Bareša: THE EFFECT OF THE COVID-19 PANDEMIC ON THE CROATIAN ...

Table 2 (continued)

\begin{tabular}{llccccc} 
Pandemic & Index & Total Change $(\%)$ & Mean & Stdev & Min & Max \\
\hline Post & CrobexTur & 22.59 & 0.09 & 1.15 & -3.223 & 5.17 \\
Pre & CrobexInd & -1.412 & -0.005 & 1.256 & -4.032 & 6.66 \\
Pre & CrobexKonstr & -31.34 & -0.114 & 2.261 & -8.131 & 6.92 \\
Pre & CrobexNutr & 42.658 & 0.156 & 1.763 & -10.66 & 8.71 \\
Pre & CrobexTr & 19.076 & 0.07 & 0.418 & -1.609 & 2.05 \\
Pre & CrobexTur & -0.43 & -0.002 & 0.623 & -2.004 & 2.87 \\
\hline
\end{tabular}

\subsection{Event study methodology}

This paper applies the event study methodology as described in Brown and Warner (1985). In order to estimate the economic impact of the event on the stock market performance, the event study procedure measures the deviation of the stock`s returns from their historical average and tests weather the influence of the event is translated into abnormal returns. Under the efficient market hypothesis, the stock market returns should reflect all available information and price adjustment to the announcement of new information follows immediately (Fama et al. 1969). Stock market returns are estimated in the pre-event time period, according to the formula:

$$
R_{i t}=\frac{P_{i, t}-P_{i, t-1}}{P_{i, t-1}}
$$

where $P_{i t}$ is the price of the stock $i$ in the period $t$. The abnormal return $A R_{i t}$ is defined as a difference between the actual and expected return $E\left[R_{i t} \mid I_{t}\right]$ during the event window:

$$
A R_{i t}=R_{i t}-E\left[R_{i t} \mid I_{t}\right]
$$

The expected returns during the event window are parametrized according to the OLS specification:

$$
E\left[R_{i t} \mid I_{t}\right]=\alpha_{i t}+\beta_{i t} R_{M K T_{i t}}+\epsilon_{i t}
$$

where $R_{M K T_{i t}}$ represents the return model of choice such as market model, capital asset pricing model (Mossin 1966), Fama-French factor model (Fama and French 1992) and Carhart (1997) four factor model. In this analysis, the market model is applied. The abnormal return $A R_{i t}$ is defined as a difference between the actual and expected return during the event window:

or differently:

$$
A R_{i t}=R_{i t}-E\left[R_{i t} \mid I_{t}\right]
$$

$$
A R_{i t}=R_{i t}-\left(\alpha_{i t}+\beta_{i t} R_{M K T_{i t}}\right)
$$

where $\alpha_{i t}$ and $\beta_{i t}$ represent estimated parameters from the ordinary least squares model. Systematical deviations of $A R_{i t}$ from 0 imply the market mispricing of the event and 
ToSEE - Tourism in Southern and Eastern Europe, Vol. 6, pp. 109-123, 2021.

S. Bogdan, L. Šikić, S. Bareša: THE EFFECT OF THE COVID-19 PANDEMIC ON THE CROATIAN ...

offer a profitable arbitrage strategy. The cumulative abnormal return CAR is computed by aggregating abnormal returns according to:

$$
\operatorname{CAR}_{(t 1, t 2)}=\sum_{t=t_{1}}^{t_{2}} A R_{t}
$$

The null hypothesis of a zero cumulative abnormal return $\left(H_{0}: C A R_{i t}=0\right)$ is tested against the alternative of a nonzero CAR $H_{0}: C A R_{i t} \neq 0$ by $t$ statistic obtained with the following procedure:

$$
\begin{gathered}
s_{A R_{i}}^{2}=\frac{1}{M_{i}-2} \sum_{t=t_{0}}^{t_{1}} e_{i t}^{2} \\
s_{C A R_{i}}^{2}=L s_{A R_{i}}^{2} \\
t(C A R)=\frac{C A R_{i}}{s_{C A R}}
\end{gathered}
$$

where $M$ is the length of the estimation window and $\mathrm{L}$ is the length of the respective event window. The analysis applies several parametric and nonparametric tests.

First, the battery of parametric tests is applied. The standard Brown and Warner (1985) "BW85" procedure that tests the hypothesis of the theoretical cross-sectional expected value being equal to zero. The test does not require cross-sectional independence and produces robust results even if event window and estimation period are simultaneous. However, it is not robust to part of the variance induced by the event. The Boehmer et al. (1991) cross-sectional "t-stat" test that assumes independence of tested series and examines weather the cross-sectional expected value equals to zero. The test is robust to the event induced variance. The standardized-residuals "pt" test from Patell (1976) that examines the hypothesis of expected theoretical cross-sectional value for a given day being equal to zero. The standardization of residuals balances out the effect of event related variance, especially when compared to Brown and Warner variants. Because of the variance standardization, the "pt" test is appropriate under the presence of a highly volatile series that would potentially influence the whole sample. The test runs under the assumption of the cross-sectional independence and allows for the overlapping of event window and estimation period but is not robust to an event induced variance. The hybrid standardized cross section test from Boehmer et al. (1991) that combines t-test and standardized results as previously described in Pattel`s procedure. The test has a null hypothesis of cross-sectional expected value being zero and runs under the assumption of cross-sectional independence. The procedure is robust to the simultaneity of event window and estimation period. Finally, the test described in Lamb (1995) that tests the hypothesis of CAR statistic being different from zero and having the advantage of being robust to the correlation in the cross-section returns. 
ToSEE - Tourism in Southern and Eastern Europe, Vol. 6, pp. 109-123, 2021.

S. Bogdan, L. Šikić, S. Bareša: THE EFFECT OF THE COVID-19 PANDEMIC ON THE CROATIAN ...

Second, to control for the robustness, several nonparametric tests are applied. The simple binomial sign test "SIGN" that indicates weather the cross-sectional frequency of abnormal returns differs from 0.5 as described in Boehmer et al. (1991). The test has good properties in the presence of outliers i.e. series with extreme abnormal returns, and non-symmetric cross sectional returns but is not robust in when the estimation period and the event period overlap. The binomial test "GSIGN" that indicates if the cross-sectional frequency of positive abnormal returns differs from the expected value. The test is also robust to outliers, non-symmetric abnormal returns but doesn't allow for the overlapping periods. The difference relative to the "SIGN" test is that "GSIGN" procedure estimates the expected frequency rather than using assumed value of 0.5. The Corrado and Zivney (1992) "CSIGN" procedure that uses rank ordering and exhibits robustness in the case of non-symmetric abnormal returns as well as variance jumps during the event window. The rank "RANK" procedure that orders abnormal returns according to the corresponding ranks. This procedure is robust to the non-symmetric abnormal returns and variance jumps but isn't suitable for the event and estimation period overlapping. The modified rank "MRANK" procedure that extends regular rank test in terms of improved ordering procedure but exhibits very similar properties. Finally, the Willcoxon test "WLCX" based on the sum of ranks statistic that correspond to the ranking of nonzero differences of cross-sectional abnormal returns is used. The test is robust to overlapping of estimation and event windows.

\section{RESULTS AND DISCUSSION}

In this analysis we broadly define the event in terms of the COVID-19 pandemic transitioning from a global shock to having a measurable effect in Europe. To proxy the event effect, the first reported case in Italy on 21 February is chosen and extended to one week prior to the event to allow for the information to become incorporated into the market valuations. The reason for extending the event period is because investors were already aware of the ongoing pandemic and the virus was already spreading through Italy before the official announcement. In a similar fashion, the end of the event period is extended by three trading days after the official lockdown was introduced in Croatia on 19 March to allow investors to process the information and adjust the market valuation accordingly. For the given period, the results of the several parametric event study tests are presented in Table 3. The table shows clusters of high significance across different tests on the first trading day after the lockdown was introduced in Italy (24 February) as well as the following day (25 February), but with somewhat less robustness. Clusters of significance across different tests are also observed around 11 March 11, when the World Health Organization declared COVID-19 a global pandemic, pointing to the significant effect on the listed tourist firms on the ZSE. It is also noticeable that robustly significant COVID-19 effects can be observed on 9, 12, 16 and 17 March, pointing to the investors' anticipation of official declarations on the local market. 
ToSEE - Tourism in Southern and Eastern Europe, Vol. 6, pp. 109-123, 2021.

S. Bogdan, L. Šikić, S. Bareša: THE EFFECT OF THE COVID-19 PANDEMIC ON THE CROATIAN ...

Table 3: The event study results for the parametric tests

\begin{tabular}{|c|c|c|c|c|c|}
\hline Date & BW85 & t-stat & $\mathrm{pt}$ & $\mathrm{BH}$ & LMB \\
\hline 17.2 .2020 & 0.154 & 0.5 & 0.938 & 0.899 & 0.154 \\
\hline 18.2.2020 & 0.548 & 1.1 & 1.799 & 1.642 & 0.547 \\
\hline 19.2.2020 & -0.73 & -1.81 & $-2.519 * *$ & -1.54 & -0.72 \\
\hline 20.2.2020 & 0.257 & 1.312 & 1.052 & 1.345 & 0.256 \\
\hline 21.2.2020 & 0.863 & 0.868 & 1.248 & 1.166 & 0.862 \\
\hline 24.2.2020 & $-4.19 * * *$ & -2.03 & $-11.66 * * *$ & $-2.24 * *$ & $-3.41 * * *$ \\
\hline 25.2.2020 & $-2.8 * * *$ & -1.75 & $-4.203 * * *$ & -1.63 & $-2.74 * * *$ \\
\hline 26.2.2020 & -0.48 & -0.53 & -0.120 & -0.07 & -0.47 \\
\hline 27.2.2020 & -0.19 & -0.26 & 0.408 & 0.191 & -0.18 \\
\hline 28.2.2020 & -0.65 & -0.76 & -1.527 & -0.88 & -0.63 \\
\hline 2.3.2020 & 1.797 & 1.335 & $3.738 * * *$ & 1.835 & 1.792 \\
\hline 3.3 .2020 & 0.256 & 0.267 & 0.089 & 0.062 & 0.255 \\
\hline 4.3.2020 & -0.37 & -0.27 & 0.23 & 0.117 & -0.37 \\
\hline 5.3 .2020 & -0.55 & -0.65 & $-2.726 * * *$ & -1.34 & -0.55 \\
\hline 6.3 .2020 & -1.38 & -1.05 & $-5.26 * * *$ & -1.57 & -1.31 \\
\hline 9.3.2020 & $-5.52 * * *$ & -1.9 & $-8.95 * * *$ & $-2.21 * *$ & $-3.25 * * *$ \\
\hline 10.3.2020 & -0.12 & -0.08 & $-2.8 * * *$ & -1.08 & -0.12 \\
\hline 11.3.2020 & $-4.91 * * *$ & $-2.26 * *$ & $-7.922 * * *$ & $-2.4 * *$ & $-4.12 * * *$ \\
\hline 12.3.2020 & $-2 * *$ & -0.63 & $-5.292 * * *$ & -1.34 & -1.1 \\
\hline 13.3.2020 & 0.603 & 0.335 & $2.03 * *$ & 0.691 & 0.475 \\
\hline 16.3.2020 & $-2.53 * *$ & -0.95 & $-7.119 * * *$ & -1.65 & -1.76 \\
\hline 17.3.2020 & $-2.2 * *$ & -1.69 & $-2.267 * *$ & -0.64 & $-2.12 * *$ \\
\hline 18.3.2020 & -1.3 & -0.73 & $-4.098 * * *$ & -0.98 & -1.18 \\
\hline 19.3.2020 & -0.44 & -0.24 & 0.248 & 0.06 & -0.43 \\
\hline 20.3.2020 & -1.08 & -1.05 & $-2.758 * * *$ & -1.1 & -1.02 \\
\hline 23.3.2020 & -0.9 & -0.56 & $-3.662 * * *$ & -1.06 & -0.82 \\
\hline
\end{tabular}

Note: $\mathrm{p}<0.01 * * *, \mathrm{p}<0.05^{* *}, \mathrm{p}<0.1 *$

To check the robustness of the results, several nonparametric tests are additionally run and the results are shown in Table 4. Nonparametric tests show overall less significance relative to the parametric tests, but point in the same direction. The first significance cluster can be observed on 20 February, one day before the first officially reported case in Italy, and another cluster is related to 11 March, the day when the WHO declared a global pandemic. Also, cluster of significance across tests is observed on 17 March and could be related to investors' anticipation of the introduction of the lockdown in the Croatia on 19 March. 
ToSEE - Tourism in Southern and Eastern Europe, Vol. 6, pp. 109-123, 2021.

S. Bogdan, L. Šikić, S. Bareša: THE EFFECT OF THE COVID-19 PANDEMIC ON THE CROATIAN ...

Table 4: The event study results for the nonparametric tests

\begin{tabular}{|c|c|c|c|c|c|c|}
\hline Date & SIGN & GSIGN & CSIGN & RANK & MRANK & WLCX \\
\hline 17.2.2020 & 0 & 0.823 & 1.103 & 1.017 & 1.017 & 40 \\
\hline 18.2.2020 & -0.58 & 0.229 & -0.276 & 0.696 & 0.696 & 43 \\
\hline 19.2.2020 & -0.58 & 0.229 & 0.827 & -0.226 & -0.226 & 20 \\
\hline 20.2 .2020 & 1.155 & $2.009 * *$ & 1.378 & 1.755 & 1.755 & 55 \\
\hline 21.2.2020 & -1.16 & -0.364 & 0.689 & 0.557 & 0.557 & 26 \\
\hline 24.2.2020 & -0.58 & 0.229 & -0.276 & -0.711 & -0.711 & 19 \\
\hline 25.2.2020 & 0 & 0.823 & 0 & -0.191 & -0.191 & 27 \\
\hline 26.2.2020 & -0.58 & 0.229 & -0.276 & -0.497 & -0.497 & 33 \\
\hline 27.2.2020 & 0 & 0.823 & 0.551 & 0.832 & 0.832 & 41 \\
\hline 28.2.2020 & 0.577 & 1.416 & 0.551 & 0.892 & 0.892 & 38 \\
\hline 2.3.2020 & 0.577 & 1.416 & 1.103 & 1.654 & 1.654 & 55 \\
\hline 3.3 .2020 & -0.58 & 0.229 & -0.276 & -0.148 & -0.148 & 34 \\
\hline 4.3.2020 & 0 & 0.823 & 0.827 & 0.269 & 0.269 & 38 \\
\hline 5.3 .2020 & -0.58 & 0.229 & 0.276 & 0.314 & 0.314 & 29 \\
\hline 6.3 .2020 & 0 & 0.823 & 0.276 & 0.358 & 0.358 & 31 \\
\hline 9.3.2020 & -0.58 & 0.229 & -0.276 & -0.653 & -0.653 & 15 \\
\hline 10.3.2020 & -1.16 & -0.364 & -0.551 & -1.05 & -1.05 & 27 \\
\hline 11.3.2020 & $-2.31 * *$ & -1.551 & -1.103 & $-2.225 * *$ & $-2.225 * *$ & $14 * *$ \\
\hline 12.3.2020 & 0 & 0.823 & 0.276 & 0.284 & 0.284 & 37 \\
\hline 13.3.2020 & -0.58 & 0.229 & -0.276 & -0.528 & -0.528 & 35 \\
\hline 16.3.2020 & 0 & 0.823 & 0 & 0.033 & 0.033 & 34 \\
\hline 17.3.2020 & $-2.31 * *$ & -1.551 & -1.103 & $-2.036 * *$ & $-2.036 * *$ & $13 * *$ \\
\hline 18.3.2020 & 1.155 & $2.009 * *$ & 0.551 & 0.959 & 0.959 & 43 \\
\hline 19.3.2020 & 0.577 & 1.416 & 0.827 & 1.288 & 1.288 & 50 \\
\hline 20.3.2020 & -1.73 & -0.958 & -0.827 & -1.526 & -1.526 & 22 \\
\hline 23.3.2020 & 0.577 & 1.416 & 0.276 & 0.396 & 0.396 & 34 \\
\hline
\end{tabular}

Note: $\mathrm{p}<0.01 * * *, \mathrm{p}<0.05^{* *}, \mathrm{p}<0.1 *$

Cumulative changes in the return series are additionally examined for two events, the first COVID-19 incidence in Italy and the WHO declaration of the COVID-19 global pandemic, which have been characterized by clustering of significance across multiple parametric and nonparametric tests. In this case, the event window is set to be shorter (10 days). Figure 2 shows the results when no control variables are included in the model, while Figure 3 is related to the extended model (i.e. market model), with Crobex index returns as a control variable. The left panel shows the results for the first COVID-19 incidence in Italy and the right panel is related to the WHO declaration of a global pandemic. In both cases, the null hypothesis of the abnormality of returns can't be rejected, since the full line, representing the stock returns, is inside the $95 \%$ confidence intervals denoted by the dotted lines. 
ToSEE - Tourism in Southern and Eastern Europe, Vol. 6, pp. 109-123, 2021.

S. Bogdan, L. Šikić, S. Bareša: THE EFFECT OF THE COVID-19 PANDEMIC ON THE CROATIAN ...

Figure 2: 10 day events study window specification without external regressors
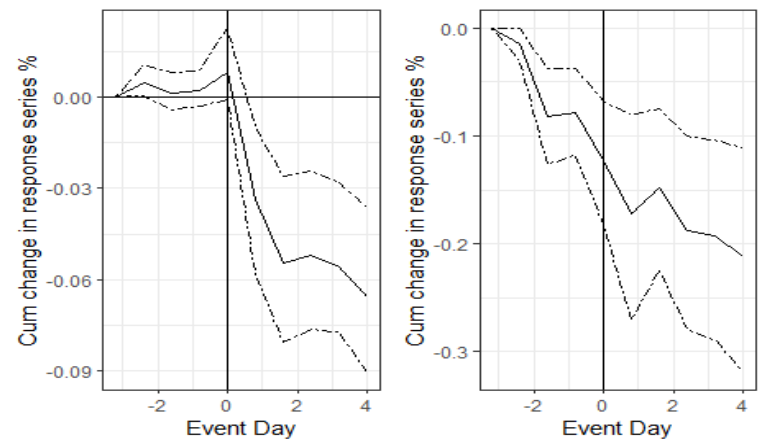

Figure 3: 10 day event study window specification with owerall market return as a control variable
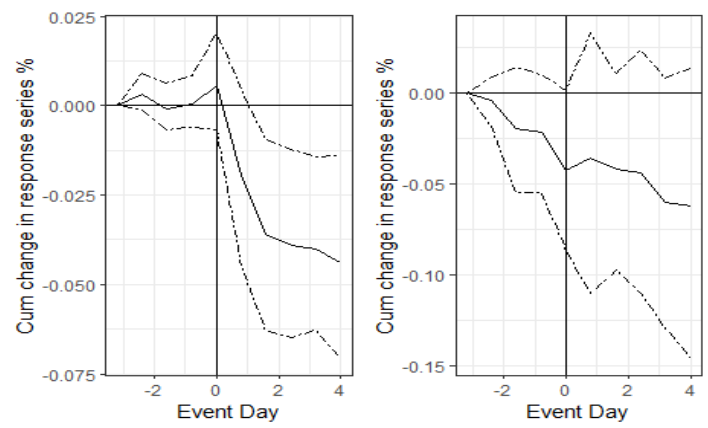

Overall, the results point to the significant negative effect of the COVID-19 pandemic on the returns of tourist stocks listed on the ZSE. When the event window is defined in broader terms, we observe clusters of significance across a variety of tests around two events, the first official incidence of COVID-19 in Italy and the WHO declaration of a global pandemic. This result implies the importance of international and global events for trends on the Croatian capital market. This result is robustly confirmed using a range of parametric and nonparametric tests. Furthermore, this finding is corroborated with a shorter event window specification and shows robustness with respect to the inclusion of external variable controlling for the overall market return. The descriptive statistics point to the significant effect of the COVID-19 pandemic on the tourist stocks in a comparable size to the general market and also to a very similar effect to the other stock market sectors. Therefore, we conclude that the COVID-19 pandemic has had an equal market-wide effect and no particular sector effect is identified. It is also interesting to note that the results imply that international events potentially carry a higher importance for the local stock market trends than the local epidemiological policy. 
ToSEE - Tourism in Southern and Eastern Europe, Vol. 6, pp. 109-123, 2021.

S. Bogdan, L. Šikić, S. Bareša: THE EFFECT OF THE COVID-19 PANDEMIC ON THE CROATIAN ...

\section{CONCLUSION}

The outbreak of the coronavirus pandemic has largely affected economic activities all over the world and governments around the globe have implemented policies that reduce the movement of people and goods. These measures are expected to have a negative impact on all economic activities and be especially pronounced in the service sector, including tourism. This analysis provides empirical evidence on the direct reactions of the ZSE-listed tourist firms to the outbreak of the global COVID-19 pandemic by means of the application of the event study methodology. The results confirm that the COVID19 pandemic affected tourist stocks by triggering a negative above-average cumulative return during the event period. Two events related to the first official COVID-19 incidence and WHO declaration of a global pandemic could be identified as the most important for returns. The findings are robust to different event window length specifications and controlling for the general market returns. Interestingly, the pandemic effects seem to be similar in size across different sectors, and the tourist sector is no exception to this rule. This result might be due to the low liquidity of tourist stocks on the ZSE or the structure of the Croatian economy and financial market, but further inquiry would be an interesting area for future research, in addition to further examining the reasons for the unequal sectoral distribution of the pandemic effects on the local and global markets.

\section{REFERENCES}

Albulescu, C. (2020), “Coronavirus and financial volatility: 40 days of fasting and fear", arXiv preprint arXiv:2003.04005, viewed 15 April 2021, https://arxiv.org/abs/2003.04005

Alam, M.N., Alam, M.S. and Chavali, K. (2020), "Stock market response during COVID-19 lockdown period in India: An event study", The Journal of Asian Finance, Economics, and Business, Vol. 7, No. 7, pp. 131-137. https://doi.org/10.13106/JAFEB.2020.VOL7.NO7.131

Asquith, P. and Mullins Jr, D.W. (1983), "The impact of initiating dividend payments on shareholders' wealth", Journal of business, Vol. 56, No. 1, pp. 77-96.

Baker, S.R., Bloom, N., Davis, S.J., Kost, K.J., Sammon, M.C. and Viratyosin, T. (2020), "The unprecedented stock market impact of COVID-19”, Working Paper No. 26945, National Bureau of Economic Research, Cambridge.

Ball, R. and Brown, P. (1968), “An empirical evaluation of accounting income numbers”, Journal of accounting research, Vol. 6, No. 2, pp.159-178.

Boehmer, E., Musumeci J. and Poulsen A.B. (1991), "Event-study methodology under conditions of eventinduced variance”, Journal of Financial Economics, Vol. 30, No. 2, pp. 253-272. https://doi.org/ 10.1016/0304-405X(91)90032-F

Brown, S.J. and Warner, J.B. (1980), "Measuring security price performance", Journal of financial economics, Vol. 8, No. 3, pp. 205-258. https://doi.org/10.1016/0304-405X(80)90002-1

Brown, S.J. and Warner, J.B. (1985), "Using daily stock returns: The case of event studies", Journal of financial economics, Vol. 14, No. 1, pp. 3-31. https://doi.org/10.1016/0304-405X(85)90042-X

Carhart, M.M. (1997), "On persistence in mutual fund performance”, The Journal of finance, Vol. 52, No. 1, pp. 57-82. https://doi.org/10.1111/j.1540-6261.1997.tb03808.x

Chia, R.C.J., Liew, V.K.S. and Rowland, R. (2020), "Daily new Covid-19 cases, the Movement Control Order, and Malaysian stock market returns", International Journal of Business and Society, Vol. 21, No. 2, pp. 553-568.

Contessi, S., and De Pace, P. (2021), "The international spread of COVID-19 stock market collapses", Finance Research Letters, Available online 6 January 2021, https://doi.org/10.1016/j.frl.2020.101894

Corrado C.J., and Zivney T.L. (1992), "The Specification and Power of the Sign Test in Event Study Hypothesis Tests Using Daily Stock Returns", Journal of Financial and Quantitative Analysis, Vol. 27, No. 3, pp. 465-478. 
ToSEE - Tourism in Southern and Eastern Europe, Vol. 6, pp. 109-123, 2021.

S. Bogdan, L. Šikić, S. Bareša: THE EFFECT OF THE COVID-19 PANDEMIC ON THE CROATIAN ...

Croatian Bureau of Statistics (2021), Tourist arrivals and nights, 2020. First Release no. 4.3.2, viewed 20 April 2021, https://www.dzs.hr/Hrv_Eng/publication/2020/04-03-02_01_2020.htm

Croatian Bureau of Statistics n.d., Statistics in line, viewed 22 April 2021, https://www.dzs.hr/Eng/Covid19/tourism-arrivals_and_nights_2020.html

Erdem, O. (2020), "Freedom and stock market performance during Covid-19 outbreak", Finance Research Letters, Vol 36: 101671. https://doi.org/10.1016/j.frl.2020.101671

Fama, E.F., Fisher, L., Jensen, M.C. and Roll, R. (1969), "The adjustment of stock prices to new information", International economic review, Vol. 10, No. 1, pp. 1-21.

Fama, E.F. and French, K.R. (2021), "The cross-section of expected stock returns", in Cochrane E.F. and Moskowitz, T.J. (Ed.), The Fama Portfolio: Selected Papers of Eugene F. Fama, University of Chicago Press, Chicago, pp. 349-391.

Kandil Göker, İ.E., Eren, B.S. and Karaca, S.S. (2020), „The Impact of the COVID-19 (Coronavirus) on The Borsa Istanbul Sector Index Returns: An Event Study", Gaziantep Üniversitesi Sosyal Bilimler Dergisi, Vol. 19, COVID-19 Special Issue, pp.14-41. https://doi.org/10.21547/jss.731980

Harjoto, M.A., Rossi, F. and Paglia, J.K. (2020), "COVID-19: Stock market reactions to the shock and the stimulus", Applied Economics Letters, pp. 1-7. https://doi.org/10.1080/13504851.2020.1781767

He, P., Sun, Y., Zhang, Y. and Li, T. (2020), "COVID-19's impact on stock prices across different sectorsAn event study based on the Chinese stock market", Emerging Markets Finance and Trade, Vol. 56, No. 10, pp. 2198-2212. https://doi.org/10.1080/1540496X.2020.1785865

Irfan, M., Kassim, S. and Dhimmar, S. (2021), "Impact of Covid-19 on Islamic Stock Markets: An Investigation using Threshold Volatility and Event Study Models", International Journal of Islamic Economics and Finance (IJIEF), Vol. 4, No. 1, pp. 121-148. https://doi.org/10.18196/ijief.v4i1.10480

Kothari, S.P. and Warner, J.B. (2007), "Econometrics of event studies", in Eckbo, B.E. (Ed.) Handbook of empirical corporate finance, Vol. 1, Elsevier, pp. 3-36. https://doi.org/10.1016/B978-0-44453265-7.50015-9

Lamb R.P. (1995), “An Exposure-Based Analysis of Property-Liability Insurer Stock Values around Hurricane Andrew”, Journal of Risk and Insurance, Vol. 62, No. 1, pp. 111-123.

Liu, H., Manzoor, A., Wang, C., Zhang, L. and Manzoor, Z. (2020), "The COVID-19 outbreak and affected countries stock markets response", International Journal of Environmental Research and Public Health, Vol. 17, No. 8: 2800. https://doi.org/10.3390/ijerph17082800

Mazur, M., Dang, M. and Vega, M. (2021), „COVID-19 and the march 2020 stock market crash. Evidence from S\&P1500", Finance Research Letters, Vol. 38: 101690. https://doi.org/10.1016/ j.frl.2020.101690

Miletić, M. (2011), „Stock price reaction to dividend announcement in Croatia“, Economic researchEkonomska istraživanja, Vol. 24, No. 3, pp. 147-156. https://doi.org/10.1080/1331677X.2011 .11517473

Ministry of Tourism of the Republic of Croatia. (2020), Turizam u brojkama 2019 [Tourism in numbers 2019], viewed 12 April 2021, https://www.htz.hr/sites/default/files/2020-07/HTZ\%20TUB\%20HR _\%202019\%20\%281\%29.pdf

Mossin, J. (1966), "Equilibrium in a capital asset market”, Econometrica, Vol. 34, No. 4, pp. 768-783.

Narayan, P.K., Devpura, N. and Wang, H. (2020), "Japanese currency and stock market-What happened during the COVID-19 pandemic?”, Economic Analysis and Policy, Vol. 68, pp. 191-198 https://doi.org/10.1016/j.eap.2020.09.014

Novak, I. (2019), "Efficient market hypothesis: case of the Croatian capital market", InterEULawEast: journal for the international and european law, economics and market integrations, Vol. 6, No. 1, pp. 3 20. https://doi.org/10.22598/iele.2019.6.1.2

Okorie, D.I. and Lin, B. (2021), "Stock markets and the COVID-19 fractal contagion effects", Finance Research Letters, Vol. 38: 101640. https://doi.org/10.1016/j.frl.2020.101640

Onali, E. (2020), “Covid-19 and stock market volatility”, Available at SSRN 3571453. http://dx.doi.org/ $10.2139 / \mathrm{ssrn} .3571453$

Panyagometh, K. (2020), "The Effects of Pandemic Event on the Stock Exchange of Thailand", Economies, Vol. 8, No. 4: 90. https://doi.org/10.3390/economies8040090

Patell J.M. (1976), "Corporate forecasts of earnings per share and stock price behavior: Empirical tests", Journal of Accounting Research, Vol. 14, No. 2, pp. 246-276.

Phan, D.H.B. and Narayan, P.K. (2020), "Country responses and the reaction of the stock market to COVID19-A preliminary exposition”, Emerging Markets Finance and Trade, Vol. 56, No. 10, pp. 21382150. https://doi.org/10.1080/1540496X.2020.1784719

Rahman, M.L., Amin, A. and Al Mamun, M.A. (2021), "The COVID-19 outbreak and stock market reactions: Evidence from Australia”, Finance Research Letters, Vol. 38: 101832. https://doi.org/10.1016/ j.frl.2020.101832 
ToSEE - Tourism in Southern and Eastern Europe, Vol. 6, pp. 109-123, 2021.

S. Bogdan, L. Šikić, S. Bareša: THE EFFECT OF THE COVID-19 PANDEMIC ON THE CROATIAN ...

Ramelli, S. and Wagner, A. (2020), "What the stock market tells us about the consequences of COVID-19", in Baldwin, R. and di Mauro, B.W., Mitigating the COVID Economic Crisis: Act Fast and Do Whatever, CEPR Press, London, pp. 63-70.

Škrinjarić, T. and Orlović, Z. (2019), "Effects of Economic and Political Events on Stock Returns: Event Study of the Agrokor Case in Croatia", Croatian economic survey, Vol. 21, No. 1, pp. 47-86. https://doi.org/10.15179/ces.21.1.2

United Nations World Tourism Organization UNWTO (2021), UNWTO World Tourism Barometer 19 (1): 142. https://doi.org/10.18111/wtobarometereng

World Health Organization n.d., WHO Health Emergency Dashboard, viewed 20 April 2021, https://covid19.who.int/

Siniša Bogdan, PhD, Assistant Professor

University or Rijeka, Faculty of Tourism and Hospitality Management

Department of Finance

Primorska 46, 51410 Opatija, Croatia

+385-51-294755

sinisab@fthm.hr

Luka Sikić, PhD, Assistant Professor

Faculty of Croatian Studies

Borongajska cesta 83d, 10000 Zagreb, Croatia

+385-1-2457600

1sikic@hrstud.hr

Suzana Bareša, PhD, Assistant Professor

University or Rijeka, Faculty of Tourism and Hospitality Management

Department of Finance

Primorska 46, 51410 Opatija, Croatia

+385-51-294193

suzanab@fthm.hr 